\title{
Proof without words
}

\author{
ZoLTÁN KÁTAI
}

Let us prove: If we add 1 to the product of four consecutive natural numbers, we get a square number:

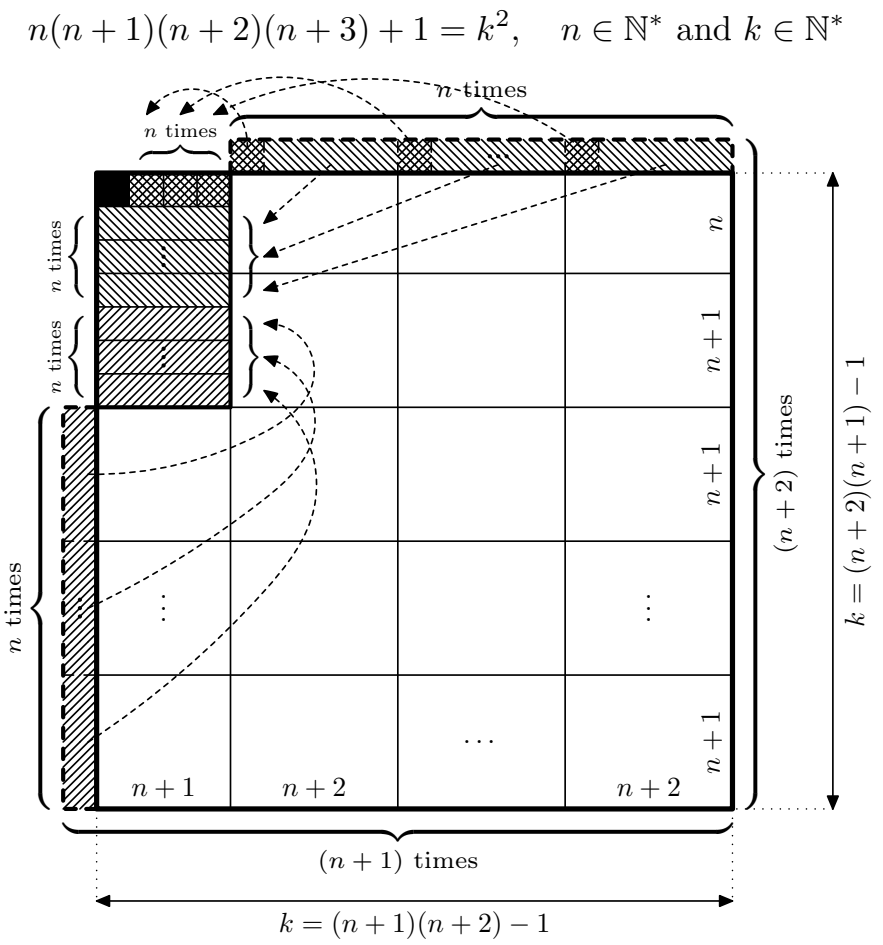

Copyright (c) 2005 by University of Debrecen 
ZOLTÁN KÁTAI

SAPIENTIA

ERDÉLYI MAGYAR TUDOMÁNYEGYETEM

MAROSVÁSÁRHELY

ROMANIA

E-mail: katai_zoltan@ms.sapientia.ro

(Received August, 2005) 